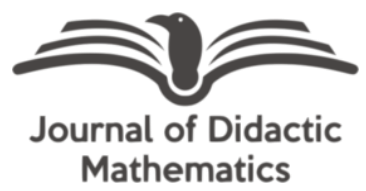

\title{
Analisis kualitas pembelajaran matematika pada penggunaan platform google classroom materi kombinatorika
}

\author{
Helma Mustika* \\ STKIP Insan Madani Airmolek, Airmolek, Riau, Indonesia, 29352 \\ Junita Nadela \\ STKIP Insan Madani Airmolek, Airmolek, Riau, Indonesia, 29352 \\ *Corresponding Author: helmamustika@gmail.com
}

\begin{abstract}
Using the background of the problem is this research is the lack of knowledge of theachers and students about how use the application Google Classroom (GC) in learning activities, but there are still students do not have google account to $\log$ in the application GC. This research is a descriptive qualiative research. This study aims to determine how the quality of mathematics learning in the use of the application GC of combinatorics material for class XII IPA students of SMA Negeri 1 Pasir Penyu. The subjects of this study were selected based on the student's daily test scores on combinatoric material using the application GC, where the subjects of this study included six students of class XII IPA 3 consisting of two students who had high test scores, two students who had mean test scores and two students who had low test scores. Data collection techniques are interview guidelines and questinnaire sheets. Furthermore, the data obtained will be analyzed based on indicators of the quality of mathematics learning. Data analyzed techniques in this study were data reduction, data presentation, and data verification. Based on the final results of the questionnaire sheets scores and the average posttest so that the average of both is 71,5 whit good categories, it can be concluded that the quality of mathematics learning in the use of the application GC of combinatorics material for class XII IPA 3 students of SMA Negeri 1 Pasir Penyu is good.
\end{abstract}

Historis Artikel:

Diterima: 11 Februari 2021

Direvisi: 26 Februari 2021

Disetujui: 04 April 2021

\section{Keywords:}

GC, Quality of Mathematics Learning, descriptive research

Sitasi: Mustika, H., \& Nadela, J. (2021). Analisis kualitas pembelajaran matematika pada penggunaan platform google classroom materi kombinatorika. Journal of Didactic Mathematics, 2(1), 1-8. Doi: 10.34007/jdm.v2i1.579

\section{PENDAHULUAN}

Pesatnya perkembangan teknologi merambah ke dalam dunia pendidikan, salah satunya penggunaan media pembelajaran berbasis teknologi. Indonesia saat ini sedang menerapkan pembelajaran jarak jauh berbasis teknologi yaitu BDR (Belajar Dari Rumah) yang mana mengharuskan siswa dan guru melakukan proses pembelajaran dengan berbantuan komputer. Banyak media yang dapat digunakan untuk menjawab permasalahan ini, salah satunya adalah platform Google Classroom (GC), karena GC dianggap platform yang terbaik (Iftakhar, 2020) termasuk di Indonesia (Rosidin et al., 2021; Sudarsana et al., 2019). Selain merupakan platform yang sangat membantu guru dan efektif (Albashtawi \& Al Bataineh, 2020), beberapa keuntungan dari penggunaan GS diantaranya; (1) mudah digunakan; (2) menghemat waktu; (3) cluud-based; (4) fleksibel; (5) Gratis; dan (6) mudah diakses melalui handphone (Janzen, 2014). Hal ini menimbulkan pertanyaan bagi penulis bagaimana kualitas pembelajaran matematika pada penggunaan platform GC ini. Sehingga penulis mengangkat judul penelitian yaitu analisis kualitas pembelajaran matematika pada penggunaan platform GC pada materi kombinatorika. 
GC dapat mempermudah guru dan peserta didik dalam melakukan proses pembelajaran karena dapat menghemat waktu sehingga dapat diakses dimana dan kapan saja dengan menggunakan koneksi jaringan internet yang memadai (Rosdiana et al., 2020; Rozak \& Albantani, 2018). Artinya, GC sebagai media yang dapat membantu proses pembelajaran peserta didik maupun guru dalam mewujudkan tujuan pendidikan. Pendidikan merupakan suatu usaha yang dilakukan secara terencana, sistematis dan logis dalam rangka membin manusia menuju proses pendewasaan sesuai dengan kebutuhan dan tuntutan hidup di lingkungannya.

Menurut Undang-Undang Nomor 20 Tahun 2003 tentang Sistem Pendidikan Nasional menyebutkan, bahwa pendidikan nasional berfungsi mengembangkan kemampuan dan membentuk watak serta peradaban bangsa yang bermartabat dalam rangka mencerdaskan kehidupan bangsa. Melalui pendidikan juga diharapkan suatu negara mampu untuk menghadapi tuntutan kemajuan zaman yang sekarang ini semakin berkembang cepat. Pendidikan juga hendaknya mampu mengembangkan potensi kecerdasan serta bakat yang dimiliki peserta didik secara optimal sehingga peserta didik dapat mengembangkan potensi diri yang dimilikinya menjadi suatu prestasi yang punya nilai jual (Shoimin, 2014). Untuk mewujudkan tujuan pendidikan nasional berbagai cara dilakukan oleh pemerintah, salah satunya adalah melaksanakan Ujian Nasional dan memasukkan mata pelajaran matematika di dalamnya (Wasida \& Hartono, 2018).

Selain menjadi pelajaran inti di setiap jenjang (Wardhani, 2008), matematika mempunyai peran penting dalam berbagai disiplin ilmu (Nurhikmayati, 2019) dalam mengembangkan daya pikir manusia (Siswono, 2016), dengan mempelajari matematika siswa lebih kritis (Hakim, 2017) dalam memahami suatu permasalahan dalam kehidupan sehari-hari. Oleh sebab itu, pelajaran matematika perlu diberikan kepada semua siswa mulai dari sekolah dasar sampai ke perguruan tinggi. Matematika merupakan ilmu universal (Puspita et al., 2013) yang mampu memberi peluang bagi terbentuknya pola pikir matematis (Hasratuddin, 2013) kemampuan berkomunikasi, berfikir, memecahkan masalah (Suwanto, 2017) dan bernalar bagi siswa (Mashuri, 2019; NCTM, 2000) Untuk dapat mengoptimalisasi tujuan matematika diperlukan pembelajaran yang efektif dan tepat sesuai kebutuhan.

Pembelajaran yang efektif dan efisien adalah pembelajaran yang dilakukan oleh siswa (student center learning), bukan dibuat untuk siswa (Ardian \& Munadi, 2016; Daulae, 2014). Pembelajaran pada dasarnya merupakan upaya pendidik untuk membantu peserta didik untuk melakukan kegiatan belajar. Belajar pada intinya tertumpu pada kegiatan memberi pengetahuan kepada peserta didik agar dapat mencapai hasil yang sesuai dengan tujuan. Salah satu faktor yang mempengaruhi hasil belajar matematika adalah metode pembelajaran yang digunakan dalam proses pembelajaran (Sutrisno \& Siswanto, 2016). Saat ini, proses pembelajaran sudah mengalami perubahan dan perkembangan yang pesat, banyak inovasi-inovasi baru yang mulai dikembangkan dalam proses pembelajaran, salah satunya adalah pemanfaatan kemajuan teknologi informasi dan komunikasi. Perkembangan teknologi informasi dan komunikasi terus meningkat seiring dengan meningkatnya kebutuhan manusia (Nugroho, 2016), termasuk dalam bidang pendidikan (Hidayat et al., 2021). Penggunaan teknologi informasi menjadikan kegiatan pembelajaran di sekolah menjadi lebih menarik, aktif dan kreatif.

Teknologi dalam dunia pendidikan biasanya disebut e-learning. Manfaat dari pemakaian fasilitas dari e-learning adalah untuk memperlancar proses belajar dan pembelajaran. Melalui $e$ learning, belajar tidak lagi dibatasi oleh ruang dan waktu. Belajar dapat dilakukan kapan saja dan dimana saja. Perkembangan e-learning memang tidak dapat dipisahkan dari teknologi internet yang mengalamai perkembangan pesat. Walaupun demikian internet merupakan media yang sangat penting dalam e-learning. Dengan internet, pembelajaran online dapat dilangsungkan. E-learning memungkinkan peserta didik untuk dapat menimba ilmu tanpa harus secara fisik hadir di kelas (Ningtyas et al., 2014; Septantiningtyas, 2018).

Hanum (2013) menyimpulkan bahwa e-learning dapat dijadikan sebagai alat bantu pada pembelajaran di sekolah. Salah satu media e-learning yang sering digunakan adalah Google. Dalam 
Analisis kualitas pembelajaran matematika pada penggunaan platform google...

hal pendidikan Google telah meluncurkan platform terbarunya yang dinamakan Google Apps For Education (GAFE). GAFE adalah sebuah teknologi yang disediakan dan dirancang bagi sekolah dan universitas dengan mengedepankan penggunaan teknologi informasi dan kolaborasi secara online. Salah satu fasilitas yang ada pada GAFE adalah GC. GC dapat diakses dengan menggunakan PC ataupun melalui ponsel dan tablet berbasis android dan iOS. Dengan GC ini maka guru dan peserta didik dapat terhubung secara digital, hal ini dapat mempermudah guru untuk memberikan materi dan tugas kepada peserta didik begitu juga sebaliknya. Salah satu keunggulan dari GC adalah peserta didik dapat melakukan diskusi secara online baik dengan guru atau peserta didik lainnya dengan menggunakan platform tersebut.

Berdasarkan hasil observasi yang peneliti lakukan, SMA Negeri 1 Pasir Penyu merupakan sekolah yang telah memanfaatkan e-learning sebagai media pembelajaran sudah selama satu setengah tahun terakhir ini. Dalam proses pembelajaran siswa diberikan penugasan oleh guru dan mengirimkan hasil laporannya ke platform GC. Selain itu juga siswa diberikan materi tambahan guna memahami lebih luas materi yang mungkin belum bisa tersampaikan langsung ketika tatap muka di kelas. Akan tetapi pada pelaksanaannya masih ada beberapa guru yang belum maksimal menggunakan platform GC pada pembelajarannya. Hal ini disebabkan karena masih kurangnya pengetahuan guru dan peserta didik tentang cara menggunakan platform GC dalam kegiatan pembelajaran. minimnya penggunaan media pembelajaran berbasis e-learning membuat peserta didik menjadi tidak antusias dalam kegiatan pembelajaran. Hal ini menjadikan peserta didik kesulitan dalam memahami pelajaran matematika yang kemudian berdampak pada rendahnya hasil belajar matematika siswa. Tentu juga akan berdampak terhadap kualitas pembelajaran. Platform GC hanya bisa diakses dengan menggunakan akun google. Sebelum menggunakan platform GC pengguna harus log in terlebih dahulu menggunakan mail google (Gmail).

GC dapat dijadikan sebagai sarana distribusi tugas, submit tugas bahkan menilai tugastugas yang dikumpulkan (Azhar \& Iqbal, 2018; Shaharanee et al., 2016). Dengan demikian, platform ini dapat memudahkan guru dan siswa dalam melaksanakan kegiatan pembelajaran. Hal ini dikarenakan baik siswa maupun guru dapat mengumpulkan tugas, mendistribusikan tugas, menilai tugas di rumah atau dimanapun tanpa terikat batas waktu atau jam pelajaran. Kualitas pembelajaran juga merupakan salah satu elemen yang sangat penting dalam sebuah pendidikan. Pembelajaran pada dasarnya merupakan kegiatan akademik yang berupa interaksi komunikasi anatara pendidik dan peserta didik proses ini merupakan sebuah tindakan professional yang bertumpu pada kaidah-kaidah ilmiah. Aktivitas ini merupakan kegiatan guru dalam mengaktifkan proses belajar peserta didik dengan menggunakan berbagai metode belajar.

Depdiknas (2004) menyatakan indikator kualitas pembelajaran dapat dikaji melalui beberapa aspek yaitu, (1) Perilaku pembelajaran pendidik (guru); (2) Aktivitas/perilaku siswa; (3) Iklim pembelajaran; (4) Materi pembelajaran; (5) Media pembelajaran; dan (6) Sistem pembelajaran. Namun kualitas pembelajaran yang dilaksanakan secara daring harus memenuhi beberapa syarat; (1) Sederhana; (2) Personal; dan (3) Cepat (Elyas, 2018). Untuk mencapai kualitas pembelajaran tersebut maka dibutuhkan strategi pembelajaran yang dapat dilakukan oleh guru, Uno (2008) membagi tiga stategi pembelajaran; (1) Strategi pengorganisasian (organizational strategy); (2) Strategi penyampaian (delivery strategy); dan (3) Strategi pengelolaan (management strategy).

Untuk mencapai kualitas pembelajaran yang diharapkan pada masa daring perlu diperhatikan faktor penentu kesuksesan seperti teknologi, karakteristik pengajar, dan karakteristik siswa (Pangondian et al., 2019) serta kendala-kendala yang harus dihadapi (Hutauruk \& Sidabutar, 2020) dampak yang ditimbulkannya (Argaheni, 2020). Dengan demikian penerapan pembelajaran melalui platform GC, belum tentu menjanjikan sebuah keberhasilan pada setiap daerah. Walaupun pembelajaran daring dianggap baik, namun pembelajaran tatap muka tidak selamanya buruk (Hamid, 2002). Ulasan mengenai platform pembelajaran daring sudah banyak (Novita \& Hutasuhut, 2020; Sudarsana et al, 2020), namun artikel yang mengulas tentang platform GC pada tingkat SMA kurang. Sehingga penulis mengadakan penelitian adalah untuk 
mendeskripsikan kualitas pembelajaran matematika pada penggunaan platform GC pada materi kombinatorika siswa kelas XII IPA SMA Negeri 1 Pasir Penyu.

\section{METODE}

Penelitian ini adalah penelitian kualitatif yang bersifat deskriptif (descriptive research), penelitian deskriptif merupakan metode penelitian yang berusaha menggambarkan dan menginterpretasikan objek apa adanya. Subjek penelitian ini adalah seorang guru matematik dan 6 siswa yang telah mempelajari kombinatorika melalaui platform GC dengan rincian 2 siswa dengan ulangan tinggi, 2 siswa dengan nilai ulangan sedang dan 2 siswa dengan nilai ulangan rendah. Dari subjek penelitian tersebut dikumpulkan data dengan dengan teknik wawancara (Edi, 2016) dan melalui angket kualitas pembelajaran (Kresnawati, 2013; Yusri \& Arifin, 2018) dengan skala likert (Bertram, 2017) untuk melihat kualitas proses pembelajaran. Kemudian kualitas pembelajaran juga ditinjau dari hasil belajar matematika pada materi kombinatorika siswa dengan instrumen tes. Selanjutnya data yang diperoleh, akan dianalisis berdasarkan indikator kualitas pembelajaran matematika. Teknik analisis data pada penelitian ini yaitu dengan cara reduksi data, penyajian data, dan verifikasi data.

\section{HASIL DAN PEMBAHASAN}

Dengan menggunakan instrumen wawancara dan lembar angket kualitas pembelajaran, penelitian mengambil data angket kualitas pembelajaran terhadap 6 siswa XII IPA 3 SMA N Pasir Penyu secara bersamaan dalam satu hari. Namun untuk wawancara dilakukan selama dua hari dimana siswa dibagi menjadi dua kelompok, dengan tujuan mendapatkan data yang lebih akurat. Kemudian untuk menperoleh informasi tentang kualitas pembelajaran dilakukan semistructer intervew kepada satu guru matematika di kelas tersebut, dilakukan selama 1 hari. Tentunya ketujuh narasumber ini sudah pernah melakukan pembelajaran menggunakan platform GC. Dari hari wawancara dan pemberian angket kepada 6 siswa dan 1 siswa diperoleh deskripsi di bawah ini.

\section{Hasil Wawancara}

Berdasarkan hasil wawancara dengan guru bidang studi matematika, dapat disimpulkan bahwa, guru telah menerapkan penggunaan platform GC ini sejak 2017 dalam pembelajaran matematika karena platform ini sangat mudah digunakan dan dinilai sangat cocok digunakan untuk pembelajaran matematika baik secara langsung (tatap muka) maupun pembelajaran jarak jauh (belajar di rumah). Walaupun platform ini memiliki kekurangan terutama di paket internet, namun penggunaan platform ini tetap menjadi primadona dikalangan pelajar dan guru itu semua karena kelebihan dan kemudahan yang disediakan oleh platform GC ini.

Berdasarkan hasil wawancara dengan 6 orang siswa dapat peneliti simpulkan bahwa, siswa mengetahui dan menyukai platform GC karena platform ini sangat mudah digunakan dalam mengumpulkan tugas serta pembelajarannya yang efisien dilakukan dimana saja. Walaupun platform ini memiliki kekurangan terutama dalam penyampaian materi, kuota internet, kecurangan dan lain sebagainya, namun penggunaan platform ini tetap menghemat waktu sehingga lebih mudah digunakan.

\section{Hasil Angket}

Berikut disajikan tabel hasil angket kualitas pembelajaran matematika yang menggunakan platform GC yang disajikan berdasarkan indikator kualitas pembelajaran. 
Analisis kualitas pembelajaran matematika pada penggunaan platform google...

\begin{tabular}{lc} 
Tabel 1. Hasil Angket Kualitas Pembelajaran & \\
\hline \multicolumn{1}{c}{ Indikator } & Skor Angket per Indikator \\
\hline Perilaku pendidik & 68 \\
Perilaku siswa & 75,5 \\
Iklim pembelajaran & 26,8 \\
Materi pembelajaran & 88,5 \\
Media pembelajaran & 38,7 \\
Sistem pembelajaran & 68,2 \\
\hline
\end{tabular}

\section{Hasil belajar Kombinatorika}

Kualitas pembelajaran matematika dapat dilihat dalam dua segi yaitu kualitas proses dan kualitas hasil. Dari segi kualitas proses dapat dilihat dari hasil angket kualitas pembelajaran yang menggunakan platform GC pada tabel 1, sedangkan kualitas hasil dapat dilihat dari hasil belajar siswa yang merupakan nilai rata-rata hasil tes materi kombinatorika yang terdiri dari tiga kali tes. Rata-rata hasil tes siswa disajikan dalam Tabel 2 berikut:

Tabe1 2. Hasil belajar materi kombinatorika

$\begin{array}{ccc}\text { Nama Siswa } & \text { Hasil Belajar } & \text { Keterangan } \\ \text { Subyek 01 } & 80 & \text { Tuntas } \\ \text { Subyek } 02 & 80 & \text { Tuntas } \\ \text { Subyek } 03 & 90 & \text { Tuntas } \\ \text { Subyek } 04 & 90 & \text { Tuntas } \\ \text { Subyek } 05 & 65 & \text { Tidak Tuntas } \\ \text { Subyek } 06 & 85 & \text { Tuntas }\end{array}$

Dari Tabel 2 dapat dilihat bahwa hasil tes siswa yang tuntas adalah 83,3\%, sedangkan hasil tes siswa yang tidak tuntas adalah $16,7 \%$. Hal ini menunjukkan bahwa, hasil belajar siswa pada materi kombinatorika menggunakan platform GC adalah baik, hal ini dapat dilihat pada tabel 2 yaitu hanya 1 dari 6 siswa yang tidak tuntas dalam tes sedangkan 5 dari 6 siswa lainnya tuntas.

Penggunaan GC yang relatif efisien (Elyas, 2018) merupakan alasan yang paling banyak disampaikan oleh responden. GC diminati dan menarik bagi mereka karena memenuhi aspek kesederhanaan, personal dan proses yang cepat (Hartanto \& Purbo, 2002). Kesederhanaan GC tampak pada menu yang ditampilkan oleh platform GC, dimana button untuk upload tugas, memerika tugas, mendownload materi dan lain sebagainya. Feedback yang diberikan oleh siswa secara personal akan membangun kepercayaan diri siswa, tanpa harus minder dengan teman yang memperoleh prestasi yang lebih baik dari dirinya. Namun dalam pemberian tugas, pengajar harus mempertimbangkan aspek kesiapan siswa dan tekanan siswa terhadap tugas yang akan diberikan, karena tersebut dapat menimbulkan kecemasan, frustasi (Alam \& Jackson, 2013) dan kebingunan (Pangondian et al., 2019). Walaupun dipandang baik dan menarik, penggunaan GC yang membutuhkan jaringan internet akan menjadi masalah besar bagi mereka yang tidak dapat mengakses internet (Elyas, 2018) dan masih banyak tantangan lain (Surahman et al., 2020).

Indikator kualitas pembelajaran yang mendapat respon tertinggi materi pembelajaran yakni 88,5 . Hal ini menunjukkan bahwa siswa menganggap bahwa materi pembelajaran yang diberikan melalui GC sangat menarik dan lebih mudah dipahami serta digunakan dalam menyelesaikan tugas yang diberikan oleh guru (Martínez-Monés et al., 2017) sehingga dapat meningkatkan kualitas pembelajaran (Supriani, 2017). Kemudian untuk indikator perilaku guru, perilaku siswa dan sistem pembelajaran masing-masing mendapatkan skor 68, 75,5 dan 68,2. Hal ini menunjukkan guru dan siswa setuju GC mudah digunakan dan dipahami dengan sistem pembelajaran yang sesuai mampu menunjang kualitas pembelajaran matematika. Kemudian dengan daring, jumlah partisipan yang ikut di dalam kelas jauh lebih besar dibading dengan tatap muka (Elyas, 2018). Namun pada indikator iklim pembelajaran menunjukkan skor yang rendah yakni 26,8, hal ini dikarenakan kurangnya interaksi antara guru dan siswa serta mengabaikan aspek akademik, aspek sosial (Bullen, 2001) dan aspek psikologi untuk mendorong 
minat belajar mereka (Hamalik, 2003). Padahal dalam proses pembelajaran harus memperhatikan kebermaknaan yang dilakukan dengan cara dialog atau interaksi (Yazdi, 2012). Walaupun proses pembelajaran GC memaksa siswa untuk aktif (Supriani, 2017), pemberian umpan balik yang tidak tepat sasaran tidak dapat meningkatkan motivasi mereka.

Hasil belajar matematika pada materi kombinatorik, dari 6 subjek, terdapat satu subjek yang tidak tuntas dalam belajar yakni sabjek 5. Subjek lima merupakan kelompok kemampuan awal rendah dengan jenis kelamin laki-laki. Pada saat pembelajaran daring, saat diskusi dan pengerjaaan tugas, perempuan lebih aktif dari pada laki-laki dikarena perempuan lebih percaya diri disbanding laki-laki saat pengerjaan tugas (Sumianingrum et al., 2017). Rendahnya hasil belajar subjek 5 juga dikarenakan kemampuan awal yang rendah serta kurangnya penguasaan dalam mengoperasian komputer.

\section{KESIMPULAN}

Penggunaan platform GC pada siswa SMA N 1 Pasir Penyu merupakan langkah tepat untuk menjaga kualitas pembelajaran matematika pada materi kombinatorika. Namun beberapa yang harus dipertimbangkan bagi siswa dengan kemampuan awal matematika yang rendah dan iklim pembelajaran, seperti menggunakan aplikasi tambahan, memberikan perhatian lebih kepada siswa yang belum siap secara kognitif maupun psikologi. Selain itu sarana dan prasarana, penguasaan teknologi dan psikologi harus diperhatikan dalam memberikan tugas kepada siswa.

\section{DAFTAR PUSTAKA}

Alam, S., \& Jackson, L. (2013). A Case Study: Are Traditional Face-To-Face Lectures Still Relevant When Teaching Engineering Courses? International Journal of Engineering Pedagogy (IJEP), 3(S4), 9. https://doi.org/10.3991/ijep.v3is4.3161

Albashtawi, A. H., \& Al Bataineh, K. B. (2020). The effectiveness of google classroom among EFL students in Jordan: An innovative teaching and learning online platform. International Journal of Emerging Technologies in Learning, 15(11), 78-88. https://doi.org/10.3991/IJET.V15I11.12865

Ardian, A., \& Munadi, S. (2016). Pengaruh Strategi Pembelajaran Student-Centered Learning dan Kemampuan Spasial terhadap Kreativitas Mahasiswa. Jurnal Pendidikan Teknologi Dan Kejuruan, 22(4), 454-466. https://doi.org/10.21831/jptk.v22i4.7843

Argaheni, N. B. (2020). Sistematik Review: Dampak Perkuliahan Daring Saat Pandemi COVID19 Terhadap Mahasiswa Indonesia. PLACENTUM: Jurnal Ilmiab Kesehatan Dan Aplikasinya, 8(2), 99-108. https://doi.org/10.20961/placentum.v8i2.43008

Azhar, K. A., \& Iqbal, N. (2018). Effectiveness of Google Classroom: Teachers' Perceptions. Prizren Social Science Journal, 2(2), 52-66.

Bertram, D. (2017). Likert Scales. Journal of Visual Impairment \& Blindness, 111(5), 488-488. https://doi.org/10.1177/0145482x1711100511

Bullen, M. (2001). e-Learning and the Internationalization Education. Malaysian Journal of Educational Technology, 1(1), 37-46.

Daulae, T. H. (2014). Menciptakan Pembelajaran yang Efektif. Forum Pedagogik, 06(02), 131-150.

Depdiknas. (2004). Peningkatan Kualitas Pembelajaran. Depdiknas.

Edi, F. R. S. (2016). Teori W awancara Psikodiagnostik. Leutika Nauvalitera.

Elyas, A. H. (2018). Penggunaan model pembelajaran e-learning dalam meningkatkan kualitas pembelajaran. Jurnal Warta, 56(04), 1-11. http://jurnal.dharmawangsa.ac.id/index.php/juwarta/article/view/4

Hakim, L. (2017). Analisis Perbedaan Antara Kurikulum KTSP dan Kurikulum 2013. Jurnal Ilmiah Didaktika, 17(2), 280-292. https://doi.org/10.22373/jid.v16i1.590

Hamalik, O. (2003). Media Pendidikan (4th ed.). Citra Aditya Bakti.

Hamid, A. A. (2002). Hamid - 2001 - e-Learning. Journal Internet and Higher Education, 4, 311-316.

Hanum, N. S. (2013). Keefetifan e-learning sebagai media pembelajaran (studi evaluasi model 
Analisis kualitas pembelajaran matematika pada penggunaan platform google...

pembelajaran e-learning SMK Telkom Sandhy Putra Purwokerto). Jumal Pendidikan Vokasi, 3(1), 90-102. https://doi.org/10.21831/jpv.v3i1.1584

Hartanto, A. A., \& Purbo, O. W. (2002). E-Learning berbasis PHP dan MySQL. Penerbit Elex Media Komputindo.

Hasratuddin. (2013). Meningkatkan Kemampuan Berpikir Kritis Siswa Smp Melalui Pendekatan Matematika Realistik. Jumal Pendidikan Matematika, 4(2). https://doi.org/10.22342/jpm.4.2.317.

Hidayat, Sukmawarti, \& Suwanto. (2021). The application of augmented reality in elementary school education. Reseach, Society and Development, 10(3), 1-6. https://doi.org/http://dx.doi.org/10.33448/rsd-v10i3.12823

Hutauruk, A., \& Sidabutar, R. (2020). Kendala pembelajaran daring selama masa pandemi di kalangan mahasiswa pendidikan matematika: Kajian kualiatatif deskriptif. Journal of Mathematics Education and Applied, 02(01), 45-51.

Iftakhar, S. (2020). Google Classroom: What Works and How. Interactive Learning Environments, 3(2), 12-18. https://doi.org/10.1080/10494820.2020.1789672

Janzen, M. (2014). Hot Team: Google Classrom. tlt.psu.edu/2014/12/04/hot-team-googleclassroom

Kresnawati, N. (2013). Korelasi Kualitas Pembelajaran Geografi dan Hasil Belajar terhadap Sikap Peduli Lingkungan Siswa Kelas XII IPS SMAN 1 Ponorogo. Jurnal Inovasi Pendidikan IPA, 1(September), 298-303. http://www.jurnal.unsyiah.ac.id/JAP/article/view/2568/2427

Martínez-Monés, A., Reffay, C., Torío, J. H., \& Cristóbal, J. A. M. (2017). Learning Analytics with Google Classroom. 1-6. https://doi.org/10.1145/3144826.3145397

Mashuri, S. (2019). Media Pembelajaran Matematika. CV. Budi Utama.

NCTM. (2000). Principles standards and for school mathematics. The National Council of Teachers of Mathematics, Inc.

Ningtyas, R., Yunianta, T. N. H., \& Wahyudi, W. (2014). Pengembangan Handout Pembelajaran Tematik Untuk Siswa Sekolah Dasar Kelas Iii. Scholaria: Jurnal Pendidikan Dan Kebudayaan, 4(3), 42. https://doi.org/10.24246/j.scholaria.2014.v4.i3.p42-53

Novita, D., \& Hutasuhut, A. R. (2020). Plus Minus Penggunaan Aplikasi-Aplikasi Pembelajaran Daring Selama Pandemi Covid-19. Unimed Medan, June, 1-11.

Nugroho, N. T. (2016). Pengaruh Penggunaan Teknologi Informasi terhadap Kinerja Karyawan (Studi Kasus Karyawan STMIK Duta Bangsa). DutaCom Jurnal, 11(1), 12-22.

Nurhikmayati, I. (2019). Implementasi STEAM Dalam Pembelajaran Matematika. Didactical Mathematics, 1(2), 41-50. https://doi.org/10.31949/dmj.v1i2.1508

Pangondian, R. A., Santosa, P. nsap, \& Nugroho, E. (2019). Faktor - Faktor Yang Mempengaruhi Kesuksesan Pembelajaran Daring Dalam Revolusi Industri 4.0. Sainteks 2019, 56-60. https://seminar-id.com/semnas-sainteks2019.html

Puspita, S. A. R., Pitadjeng, \& Nugraheni, N. (2013). Peningkatan Kualitas Pembelajaran Geometri Berbasis Discovery Learning Melalui Model Think Pair Share. Joyful Learning Journal, 2(3), 1-9. https://doi.org/10.15294/jli.v2i3.2058

Rosdiana, L. A., Sukawati, S., \& Firmansyah. (2020). Meningkatkan Kesiplinan melalui Google Classroom dalam Mata Kuliah Bahasa Indonesia. Sematik, 9(1), 1-13. https://doi.org/10.22460/semantik.vXiX.XXX

Rosidin, U., Widyastuti, Rakhmawati, I., \& Kadaritna, N. (2021). Pelatihan Aplikasi Learning Managemen System bagi Guru SMA n 1 Gedong Tataan untuk Meningkatkan Kualitas Pembelajaran Daring. Jurnal Pendidikan Nasional, 2(1), 41-50.

Rozak, A., \& Albantani, A. M. (2018). Desain Perkuliahan Bahasa Arab Melalui Google Classroom. Arabiyat: Jurnal Pendidikan Bahasa Arab Dan Kebahasaaraban, 5(1), 83-102. https://doi.org/10.15408/a.v5i1.7481

Septantiningtyas, N. (2018). Pengaruh Pembelajaran Jarak Jauh Dengan Aplikasi Google Class Terhadap Hasil Belajar Mahasiswa. Edureligia; Jurnal Pendidikan Agama Islam, 2(2), 131-135. 
https://doi.org/10.33650/edureligia.v2i2.714

Shaharanee, I. N. M., Jamil, J. M., \& Rodzi, A. S. S. M. (2016). The application of Google Classroom as a tool for teaching and learning. Journal of Telecommunication, Electronic and Computer Engineering, 8(10), 5-8.

Shoimin, A. (2014). Inovatif dalam Kurikulum 2013. Ar-Ruzz Media.

Siswono, T. Y. E. (2016). Berpikir Kritis dan Berpikir Kreatif sebagai Fokus Pembelajaran Matematika. Seminar Nasional Matematika Dan Pendidikan Matematika (Senatik 1), 11-26.

Sudarsana, I. K., et al. (2020). COVID-19: Perspektif Pendidikan (Issue October).

Sudarsana, I. K., Putra, I. B. M. A., Temon, A. I. N., \& Yogantara, I. W. L. (2019). The use of Google classroom in the learning process. Journal of Physics: Conference Series, 1175(1), 1-5. https://doi.org/10.1088/1742-6596/1175/1/012165

Sumianingrum, N. E., Wibawanto, H., \& Haryono. (2017). Efektivitas Metode Discovery Learning Berbantuan E-Learning di SMA Negeri 1 Jepara. IJCET, 6(1), 27-35. https://doi.org/10.26858/pembelajar.v1i1.3710

Supriani, Y. (2017). Menumbuhkan Kemandirian Belajar Matematika Siswa Berbantuan Quipper School. JIPMat, 1(2). https://doi.org/10.26877/jipmat.v1i2.1248

Surahman, E., Santaria, R., \& Setiawan, E. I. (2020). Tantangan Pembelajaran Daring Di Indonesia. Journal of Islamic Education Management, 5(2), 89-98.

Sutrisno, V. L. P., \& Siswanto, B. T. (2016). Faktor-Faktor Yang Mempengaruhi Hasil Belajar Siswa Pada Pembelajaran Praktik Kelistrikan Otomotif Smk Di Kota Yogyakarta. Jurnal Pendidikan Vokasi, 6(1), 111. https://doi.org/10.21831/jpv.v6i1.8118

Suwanto. (2017). Peningkatan Kemampuan Pemecahan Masalah Matematis Siswa melalui Pembelajaran Kooperatif Berbasis Multiple Intelligence di Kelas VIII SMP Budisatrya Medan. MES Journal of Mathematics Education and Science), 3(1), 73-81. https://doi.org/https://doi.org/10.30743/mes.v3i1.222

Uno, H. B. (2008). Perencanaan Pembelajaran. Bumi Aksara.

Wardhani, S. (2008). Analisis SI dan SKL mata pelajaran matematika SMP/MTs untuk optimalisasi tujuan mata pelajaran matematika. PPPPTK Matematika.

Wasida, M. R., \& Hartono, H. (2018). Analisis kesulitan menyelesaikan soal model ujian nasional matematika dan self-efficacy siswa SMA. Jurnal Riset Pendidikan Matematika, 5(1), 82. https://doi.org/10.21831/jrpm.v5i1.10060

Yazdi, M. (2012). E-Learning sebagai Media Pembelajaran Interaktif berbasis Teknologi Informasi. Jurnal Ilmiah Foristek, 2(1), 143-152.

Yusri, Y., \& Arifin, S. (2018). Desain Pembelajaran Kooperatif Berbasis Teori Bruner Untuk Meningkatkan Kualitas Pembelajaran Matematika. HISTOGRAM: Jurnal Pendidikan Matematika, 2(2), 147-158. https://doi.org/10.31100/histogram.v2i2.233 